\title{
Pembelajaran Sejarah dan Kebebasan Berpikir
}

\author{
History Learning and Freedom of Thought \\ Yusuf Budi Prasetya Santosa ${ }^{1 \bowtie}$, Hendi Irawan ${ }^{2}$ \\ $1 \bowtie{ }^{2}$ Universitas Indraprasta PGRI \\ E-mail: prasetyabudi29@gmail.com ${ }^{凶}$, hendiirawankesos@gmail.com
}

Diterima: 29 Oktober 2020 | Direvisi: 14 November 2020 | Diterbitkan: 16 November 2020

\section{ARTICLE INFO}

Keywords:

History Learning,

Freedom of Thought, Common Sense.

\section{ABSTRACT}

Learning is part of the educational process carried out by teachers and students. One of the lessons carried out is history learning. A part of the history learning process is still dominated by history teachers. Students feel they are not actively involved in the history learning process. History teachers still respect historical knowledge without providing sufficient opportunities for students. History learning should provide opportunities to think logically for students. Freedom of thought in learning history will have a positive impact on learning history itself and students. The purpose of this study is intended to provide a perspective on the importance of providing freedom of thought in history learning for students. The method used in this research is literature study, both technical and non-technical literature. The result was found that freedom of thought in history learning can make the learning process dynamic. Freedom of thought can develop students' logical and systematic reasoning abilities. Differences in interpretation due to diversity of thinking make the learning process run dialectically.

Pembelajaran adalah bagian dari proses pendidikan yang dilakukan oleh guru dengan peserta didik. Salah satu pembelajaran yang dilakukan ialah pembelajaran sejarah. Sebagian dari proses pembelajaran sejarah masih didominasi oleh guru sejarah. Peserta didik merasa tidak dilibatkan secara aktif dalam proses pembelajaran sejarah. Guru sejarah masih menghegomoni pengetahuan kesejarahan tanpa memberikan kesempatan yang cukup bagi peserta didik. Pembelajaran sejarah seharusnya memberikan kesempatan berpikir secara nalar bagi peserta didik. Kebebasan berpikir dalam pembelajaran sejarah akan berdampak positif bagi pembelajaran sejarah itu sendiri dan peserta didik. Tujuan penelitian ini dimaksudkan untuk memberikan sebuah sudut pandang akan pentingnya memberikan kebebasan berpikir dalam pembelajaran sejarah bagi peserta didik. Metode yang digunakan di dalam penelitian ini ialah studi literatur, baik literatur teknis maupun non-teknis. Hasilnya ditemukan bahwa kebebasan berpikir dalam pembelajaran sejarah dapat membuat proses pembelajaran menjadi dinamis. Kebebasan berpikir dapat mengembangkan kemampuan penalaran peserta didik secara logis dan sistematis. Perbedaan interpretasi akibat keberagaman berpikir menjadikan proses pembelajaran berjalan secara dialektis.

\section{PENDAHULUAN}

Pembelajaran merupakan serangkaian kegiatan yang dilakukan oleh individu untuk mendapatkan sebuah pengalaman atau ilmu pengetahuan. Kegiatan pembelajaran memiliki persamaan dan perbedaan dengan kegiatan belajar. Persamaan keduanya adalah kegiatan yang bertujuan untuk mendapatkan (ilmu) 
Santosa, Irawan, 2020, Pembelajaran Sejarah dan ...

pengetahuan. Perbedaannya, belajar tidak selalu merupakan proses interaksi yang terjadi antar individu, atau belajar biasanya bukan merupakan serangkaian kegiatan yang terencana atau direncanakan. Sedangkan, pembelajaran ialah suatu aktivitas mengorganisasi atau mengatur lingkungan sebaik-baiknya dan menghubungkannya dengan anak didik sehingga terjadi proses pembelajaran (Sugihartono, Harahap, Setiawati, \& Nurhayati, 2007). Jadi pembelajaran merupakan kegiatan yang sengaja dibuat atau direncanakan.

Proses pembelajaran sendiri merupakan bagian dari pendidikan. Pendidikan dibagi menjadi dua, yaitu pendidikan formal dan informal. Proses pembelajaran terjadi pada pendidikan formal yang berlangsung di sekolah. Pembelajaran merupakan inti dari proses pendidikan secara keseluruhan, dengan guru sebagai peranan utama (Asep \& Abdul, 2008). Pembelajaran merupakan suatu proses yang mengandung serangkaian perbuatan guru dan peserta didik atas dasar hubungan timbal balik yang berlangsung dalam situasi edukatif untuk mencapai tujuan tertentu. Di dalam proses pembelajaran, baik guru maupun peserta didik bersama-sama menjadi objek dan subjek pembelajaran.

Penelitian Santosa (2017) mengemukakan jika ditemukan tiga permasalahan dalam proses pembelajaran sejarah. Pertama, proses pembelajaran yang cenderung monoton dan terjadi hanya satu arah. Kedua, ketidaktahuan guru sejarah akan filosofi pendidikan sejarah. Ketiga, ketidakpahaman guru akan kedudukan dan tujuan dari pendidikan sejarah. Ketiga permasalahan tersebut membuat peserta didik menjadi pasif di dalam proses pembelajaran, karena tidak merasa dilibatkan. Terbatasnya keterlibatan peserta didik secara tidak langsung juga berakibat pada perkembangan psikologis dan emosional bagi peserta didik, serta bukan proses pembelajaran yang merdeka.

Salah satu proses pembelajaran yang berlangsung ialah pembelajaran sejarah. Pada proses pembelajaran sejarah, pada umumnya guru sejarah masih menggunakan metode pembelajaran konvensional, seperti ceramah. Pada metode ini guru sejarah menerangkan materi dan peserta didik hanya mendengarkan serta mencatat saja, sehingga keaktifan dalam pembelajaran tidak ada (Suswandari, Lukman, \& Absor, 2020). Penggunaan metode atau model pembelajaran oleh seorang guru sejarah berpengaruh dalam keaktifan belajar peserta didik. Seorang guru sejarah dapat menggunakan berbagai metode ataupun model mengajar untuk mencapai tujuan pengajaran. Metode atau model pembelajaran yang dipakai dapat menarik perhatian peserta didik sehingga dapat meningkatkan keaktifan dan hasil belajar peserta didik dalam proses pembelajaran sejarah.

Akan tetapi, pembelajaran sejarah bukan hanya perihal model dan metode pembelajaran dan hasil pembelajaran peserta didik. Perhatian guru sejarah tidak boleh tersita hanya pada masalah model dan metode pembelajaran. Model dan metode pembelajaran hanya salah satu indikator keberhasilan pembelajaran sejarah. Hasil belajar peserta didik berupa nilai atau skor yang diraih melalui berbagai evaluasi bukanlah tujuan utama dari pembelajaran sejarah. Guru sejarah seharusnya tidak melupakan tujuan dan esensi pembelajaran sejarah, yaitu untuk membentuk manusia 
Indonesia yang berkarakter. Selain itu pembelajaran sejarah bukan hanya bicara soal deretan fakta dan data sejarah, namun pembelajaran sejarah yang dapat berimplikasi atas kehidupan sehari-hari peserta didik.

Proses pembelajaran sejarah seharusnya juga mempengaruhi kebebasan berpikir peserta didik. Proses pembelajaran sejarah yang didominasi oleh guru atau teacher center learning cenderung tidak memberikan kebebasan berpikir kepada peserta didik. Peserta didik dijejali berbagai macam fakta dan data sejarah, serta seringkali tidak dibarengi dengan proses pengolahan fakta-fakta dan data tersebut. Peserta didik seharusnya diberikan kebebasan untuk berpikir agar kebiasaan berpikir kritis dan analitis dapat tumbuh. Belum lagi guru sejarah yang menjadikan buku paket atau buku cetak sejarah sebagai satu-satunya sumber belajar, sehingga fakta dan data sejarah yang terdapat di dalam buku sejarah menjadi fakta absolut yang tidak dapat dibantah.

Pada Kurikulum 2013 ini pendekatan pembelajaran yang digunakan ialah pendekatan saintifik atau berbasis pada pengalaman peserta didik dan berorientasi pada peserta didik atau student center learning. Keduanya seharusnya memberikan peserta didik kemerdekaan dalam belajar, sekaligus kebebasan dalam berpikir. Namun, proses pembelajaran sejarah yang selama ini berlangsung, terlihat guru sejarah masih berkutat pada cara agar pembelajaran sejarah dapat diterima oleh peserta didik. Proses pembelajaran sejarah yang dilaksanakan rata-rata belum masuk pada substansi dari pembelajaran sejarah, yaitu tentang implementasi nilai-nilai. Peserta didik tetap menjadi objek pembelajaran yang seakan-akan dilarang untuk membebaskan pemikirannya sendiri, sebab pada akhirnya semua harus dikembalikan pada pakem yang sama, yakni guru sejarah dan sumber belajar.

Sehingga, muncul pertanyaan: (1) Apakah pembelajaran sejarah sudah memberikan kebebasan berpikir kepada peserta didik? dan (2) Bagaimana kebebasan berpikir dalam pembelajaran sejarah? Dengan demikian, tujuan dari penelitian ini adalah untuk memberikan sebuah sudut pandang akan pentingnya memberikan kebebasan berpikir dalam pembelajaran sejarah bagi peserta didik.

\section{METODE}

Metode yang digunakan dalam penelitian ini ialah studi literatur yang dimaksudkan untuk mengungkapkan berbagai teori yang relevan dengan permasalahan yang sedang diteliti. Teknik ini dilakukan dengan cara membaca, mempelajari, dan mengkaji literatur-literatur yang berhubungan dengan pembelajaran sejarah dan kebebasan berpikir. Pengkajian literatur yang dilakukan adalah literatur teknis dan literatur non-teknis (Strauss \& Corbin, 2009). Literatur teknis terdiri dari laporan atau karya tulis dalam bentuk jurnal ilmiah dan makalah teoretis. Sedangkan, literatur nonteknis seperti: buku teks sebagai catatan utama atau pendukung. Menurut Faisal (2005), hasil studi literatur dapat dijadikan masukan dan landasan dalam menjelaskan dan merinci masalah-masalah yang akan diteliti, termasuk juga memberi latar belakang masalah penting untuk diteliti. 
Santosa, Irawan, 2020, Pembelajaran Sejarah dan ...

\section{HASIL DAN PEMBAHASAN}

\section{Tantangan Pembelajaran Sejarah Dewasa Ini}

Sejarah dalam bahasa Indonesia menyerap dari bahasa Arab, yaitu 'syajaratun' yang artinya pohon. Kata sejarah dalam bahasa Inggris adalah 'history' yang diambil dari bahasa Yunani, 'historia' yang berarti sesuatu yang diketahui dari hasil penyelidikan atau ilmu atau research. Jadi, inti kandungan sejarah sejak awal sampai sekarang sebenarnya adalah suatu disiplin yang merupakan produk dari suatu penelitian (Sjamsuddin, 2016). Sehingga, sejarah merupakan hasil dari sebuah penelitian yang menggunakan kaidah keilmuan atau ilmiah.

Di dalam sejarah, manusia adalah inti, sebab tanpa manusia sejarah tidak akan ada, dan sebaliknya. Sejarah lahir dari segala pengalaman manusia di masa lampau. Jadi di dalam sejarah, manusia adalah subjek dan objek sekaligus. Segala sesuatu yang telah dilakukan, atau dipikirkan, atau dirasakan oleh manusia, baik individu maupun kelompok adalah sejarah. Namun, tidak semua hal atau peristiwa masa lampau dapat digolongkan menjadi sejarah, melainkan hanya hal dan peristiwa penting, yang berpengaruh kepada masyarakat luas yang dapat disebut sebagai sejarah. Sejarah sendiri tidak hanya berisi mengenai fakta-fakta sejarah, melainkan terdapat nilai-nilai yang terkandung dalam setiap peristiwa sejarah.

Sejarah diajarkan di sekolah-sekolah yang notabene merupakan institusi pendidikan formal dan legal dalam sebuah pembelajaran sejarah. Pembelajaran sejarah diberikan di seluruh jenjang pendidikan, mulai dari tingkat dasar (SD) sampai tingkat menengah, baik tingkat pertama maupun atas (SMP/SMA). Pemerintah sebagai pemegang otoritas pendidikan nasional di dalam Peraturan Menteri Pendidikan Nasional Nomor 22 Tahun 2006 Tentang Standar Isi dikatakan tujuan pembelajaran sejarah yaitu untuk membentuk watak dan peradaban bangsa yang bermartabat, serta membentuk manusia Indonesia yang memiliki rasa kebangsaan dan cinta tanah air.

Menurut Hasan (2007), tujuan kurikulum pendidikan sejarah diasosiasikan dengan tiga pandangan. Pertama adalah 'perenialisme', pembelajaran sejarah merupakan wahana transmission of culture. Pembelajaran sejarah hendaknya diberikan sebagai pengetahuan yang dapat membawa peserta didik kepada penghargaan terhadap pencapaian di masa lalu atau the glorious past. Pencapaian di masa lalu perlu untuk diberikan kedudukan yang tinggi oleh generasi sekarang dan diharapkan dapat memperuat rasa persatuan nasional. Kedua ialah 'esensialisme', pembelajaran sejarah sebagai disiplin ilmu yang tidak hanya terbatas pada transfer pengetahuan sejarah. Pembelajaran sejarah sebaiknya bertujuan untuk menumbuhkan kemampuan berpikir kritis dan analitis yang kemudian dikaitkan dalam konteks berpikir yang didasarkan pada filsafat keilmuan. Ketiga adalah rekonstruksi sosial, pembelajaran sejarah harus diarahkan pada kajian yang menyangkut kehidupan masa kini dengan problem hari ini. Pembelajaran sejarah sebaiknya memiliki peran praktis dalam kehidupan sehari-hari peserta didik.

Pada proses pembelajaran sejarah di sekolah, guru sejarah memiliki andil yang besar. Salah satu indikator keberhasilan pembelajaran sejarah adalah kompetensi dari guru sejarah. Oleh karena itu, tugas seorang guru sejarah 
tidak mudah, sebab dewasa ini tantangan pendidikan sejarah kian besar dan berat. Belum lama beredar wacana pemerintah yang hendak menghapuskan mata pelajaran sejarah dari kurikulum. Namun, hal itu telah dibantah oleh Menteri Pendidikan dan Kebudayaan melalui akun media sosial resmi Kemdikbud, yakni Twitter dan Facebook (Fakta, 2020). Meskipun telah diklarifikasi pemberitaan mengenai wacana penghapusan mata pelajaran sejarah dari kurikulum telah membuat resah banyak kelompok, seperti para sejarawan, guru sejarah, dan perguruan tinggi pencetak guru sejarah.

Akan tetapi, hal yang menarik justru bukan pada pemberitaan mengenai wacana penghapusan mata pelajaran sejarah, melainkan tanggapan sebagaian masyarakat yang tidak menyukai pelajaran sejarah. Banyak yang berpikiran, sejarah adalah pelajaran menghapal tanggal dan nama belaka, serta materi yang dianggap terlalu banyak (Matanasi, 2016). Adanya polemik mengenai penghapusan mata pelajaran sejarah dari kurikulum pendidikan sebaiknya dijadikan bahan refleksi dan evaluasi bersama oleh insitusi pendidikan tinggi yang menghasilkan calon guru sejarah dan sejarawan.

Proses pembelajaran sejarah di tingkat sekolah sebaiknya berlangsung secara dinamis, maksudnya ialah didalam proses pembelajaran sejarah terdapat dialog antara peserta didik dan guru yang mendorong keterlibatan peserta didik secara aktif. Namun yang terjadi tidak demikian karena seringkali guru mendominasi proses pembelajaran sejarah. Hal ini membuat sebagian peserta didik menganggap bahwa mata pelajaran sejarah adalah mata pelajaran yang tidak menarik, membosankan dan sulit untuk dipahami (Alfian dan Sayono dalam Absor, 2020). Asumsi atas pelajaran sejarah yang seperti itu diakibatkan ketidaktahuan peserta didik akan alasan dan pertanyaan mengapa mereka harus melakukan itu.

Kemudian banyak guru sejarah masih terjebak pada paradigma lama, yaitu kegagalan pembelajaran sejarah diakibatkan oleh penggunaan model dan metode pembelajaran yang tidak tepat. Hal ini membuat guru sejarah lebih fokus pada permasalahan teknis dalam pembelajaran dan cenderung mengabaikan subtansi pembelajaran sejarah. Pelaksanaan pendidikan sejarah seperti kehilangan arah dan cenderung melupakan pandangan perenialisme, esensialisme, dan konstruksi sosial dalam pembelajaran sejarah. Padahal, pandangan tersebut seharusnya hadir dan dipenuhi oleh guru sejarah dalam proses pembelajaran sejarah.

Perkembangan tekonologi juga menjadi tantangan bagi pendidikan secara umum, dan khususnya bagi pembelajaran sejarah dewasa ini (Absor, 2020). Kemajuan teknologi adalah sesuatu yang tidak bisa dihindari, karena kemajuan teknologi terus berjalan sejalan dengan perkembangan ilmu pengetahuan. Peserta didik sekarang akan lebih mudah mengakses berbagai sumber belajar dari teknologi yang mereka miliki. Tidak heran jika guru sejarah bersikap menutup diri dan cenderung menghegemoni pengetahuan, respons peserta didik menjadi pasif dalam pembelajaran. Hal ini bukan perihal model dan metode yang guru gunakan, akan tetapi sesuatu yang guru sampaikan kemungkinan sudah 
Santosa, Irawan, 2020, Pembelajaran Sejarah dan ...

diketahui oleh peserta didik. Pelbagai pengetahuan termasuk sejarah, kini dapat peserta didik peroleh melalui teknologi gawai pintar yang mereka miliki, bahkan bisa lebih lengkap dan kompleks daripada yang dimiliki oleh guru sejarah.

Atas situasi tersebut guru sejarah perlu melakukan evaluasi secara menyeluruh terhadap proses pembelajaran yang telah dilaksanakan. Tidak hanya evaluasi atas respons peserta didik atau model dan metode yang guru sejarah gunakan, akan tetapi perlu juga menilik kesesuaian proses pembelajaran dengan tujuan sebenarnya (perenial, esensial, dan konstrusi sosial). Kemudian guru sejarah harus memiliki pemikiran yang terbuka dan sadar jika hegemoni atas pengetahuan, khususnya pengetahuan sejarah sudah tidak relevan. Orientasi pembelajaran berdasarkan Kurikulum 2013 harus berpusat pada peserta didik, dengan begitu guru bukan lagi sumber pengetahuan. Pendekatan pembelajaran juga mengalami perubahan dalam Kurikulum 2013 menjadi pendekatan yang berdasarkan pengalaman pribadi peserta didik atau disebut sebagai saintifik.

\section{Kebebasan Berpikir dalam Pembelajaran Sejarah}

Proses pendidikan sejarah selain cenderung monoton dan kurang diminati peserta didik, guru sejarah juga seperti tidak memberikan ruang yang cukup kepada peserta didik dalam kebebasan berpikir. Guru sejarah memang memiliki tugas untuk menyampaikan narasi sejarah sesuai dengan kurikulum yang telah dibuat oleh pemerintah. Pada Kurikulum 2013, pemerintah juga telah menerbitkan buku cetak yang befungsi sebagai buku pegangan dalam pembelajaran sejarah. Akan tetapi, sebagai pegangan pembelajaran sebaiknya guru sejarah tidak menjadikan buku cetak sebagai satusatunya sumber belajar. Proses pembelajaran di dalam Kurikulum 2013 memberikan kebebasan bagi guru dan peserta didik untuk menggunakan berbagai sumber belajar. Kemajuan tekonologi yang pesat juga menjadikan sumber belajar semakin tidak terbatas.

Tidak dibatasinya sumber belajar dalam pembelajaran sejarah membuat peserta didik dapat dengan bebas mengakses berbagai pengetahuan sejarah dari sumber manapun. Hal ini berdampak pada semakin banyak dan beragamnya pengetahuan kesejarahan yang peserta didik dapatkan. Sayangnya hal ini terkadang tidak sejalan dengan sikap sebagian guru sejarah yang masih menghegemoni pengetahuan sejarah atau menjadikan buku cetak sebagai satu-satunya sumber pembelajaran yang valid. Sehingga, sering terjadi perbedaan pandangan antara guru dan peserta didik. Kochhar (2008) menjelaskan bahwa guru sejarah memiliki peranan penting dalam keseluruhan proses pembelajaran sejarah. Salah satunya, guru sejarah berperan dalam perkembangan kemampuan berpikir kreatif, kritis, dan analitis peserta didik. Agar kemampuan peserta didik dapat berkembang dengan baik ialah dengan cara memberikan mereka kebebasan berpikir.

Kebebasan berpikir dibutuhkan oleh manusia dalam kehidupannya. Dengan memikirkan segala kemungkinan yang ada, maka manusia akan mencari tahu kebenaran dari berbagai ide yang muncul di dalam pikiran. Definisi yang paling umum dari berpikir adalah perkembangan ide dan konsep (Bochenski, 2001). Di dalam hal 
ini kebebasan berpikir akan melahirkan berbagai perkembangan dan kemajuan. Pada pembelajaran sejarah, kebebasan berpikir perlu diberikan kepada peserta didik. Pemberian ini bertujuan untuk melatih dan mengembangkan kemampuan mereka dalam mengolah fakta dan data sejarah. Pembelajaran sejarah yang baik ialah mengolah berbagai fakta sejarah tersebut untuk kemudian dapat dilihat hubungannya, sebabnya, dan implikasinya di hari ini dan kemudian hari. Proses pembelajaran sejarah seperti itu erat hubungannya dengan proses berpikir.

Pada proses berpikir, individu membuat hubungan antara objek yang menjadi pokok permasalahan dengan bagian-bagian pengetahuan yang sudah dimilikinya. Bagian dari pengetahuan adalah segala sesuatu yang sudah diperolehnya dalam wujud pengertianpengertian. Proses pembelajaran sejarah yang memberikan kebebasan berpikir kepada peserta didiknya memang akan menimbulkan berbagai perspektif dan interpretasi. Namun hal tersebut bukanlah permasalahan yang harus dikhawatirkan oleh guru. Semakin beragam argumentasi dan interpretasi peserta didik tentang sebuah peristiwa sejarah, maka semakin baik kemampuan peserta didik. Guru sejarah sebaiknya memahami sebagai disiplin ilmu, pembelajaran sejarah tidak hanya terbatas pada transfer pengetahuan saja atau esensialisme.

Menurut Kemdikbud (2017), salah satu tujuan mata pelajaran sejarah, yaitu mengembangkan perilaku yang didasarkan pada nilai dan moral yang mencerminkan karakter diri, masyarakat, dan bangsa. Tujuan tersebut tidak akan dicapai jika proses pembelajaran sejarah hanya berfokus pada kegiatan menghafal berbagai fakta keras sejarah dan definisi yang dituliskan dalam buku cetak. Tujuan pembelajaran sejarah akan tercapai tanpa melalui proses penalaran, yakni berpikir secara logis dan sistematis. Cara berpikir yang tidak logis dan tidak analitis tidak termasuk ke dalam penalaran (Sumantri, 2003). Kebenaran yang didapatkan dengan proses berpikir yang tidak termasuk penalaran, tentu bersifat subjektif. Namun, justru pembelajaran sejarah secara proses tidak seideal itu. Perbedaan padangan antar peserta didik maupun dengan guru sejarah akan menciptakan proses pembelajaran sejarah yang dialektis.

Kebenaran objektif memang menjadi tujuan dari proses pembelajaran sejarah, namun untuk mencapai kebenaran objektif sebaiknya guru memberikan peserta didik kebebasan berpikir agar tercipta pembelajaran sejarah yang dialogis dan dialektis. Kebebasan berpikir tidak terikat oleh nilai-nilai tertentu, dalam artian apapun boleh untuk dipikirkan. Kebebasan berpikir tidak berarti pembenaran atas hasil sebuah pemikiran. Kebebasan berpikir tidak berbahaya selama hasilnya tidak dipandang absolut. Pada konteks ini, betapapun baik dan validnya sebuah hasil pemikiran harus dipahami sebagai sebuah kenisbian, yang terbuka dan dinamis (dialektis).

Pada pembelajaran sejarah, kebebasan berpikir akan berpengaruh pada proses pembelajaran dan peserta didik. Proses pembelajaran tidak hanya akan menjadi hidup, dalam artian menyenangkan dan komunikatif, melainkan juga peserta didik akan memahami bahwa pembelajaran sejarah harus dianggap merupakan proses yang serius. Selain itu, 
Santosa, Irawan, 2020, Pembelajaran Sejarah dan ...

kebebasan berpikir akan melatih kemampuan penalaran peserta didik, sebab pembelajaran sejarah memerlukan kemampuan penalaran yang baik. Peserta didik juga akan merasa jika eksistensi atau keberadaan mereka dalam proses pembelajaran diperhatikan karena diberikan ruang yang cukup untuk mengemukakan sesuatu yang mereka pikirkan.

Implementasi kebebasan berpikir pada pembelajaran sejarah dapat dilakukan oleh guru melalui penggunaan berbagai model dan metode pembelajaran yang mendorong peran aktif peserta didik. Misalnya model pembelajaran inkuiri, discovery, atau pemecahan masalah, yang dipadukan dengan metode diskusi atau penelitian sederhana. Guru sejarah harus berjarak dengan peserta didik dalam proses pembelajaran, dalam arti memberikan kebebasan dan ruang cukup bagi peserta didik untuk mengaktualisasikan dirinya dalam mengolah fakta dan data sejarah. Termasuk membiarkan peserta didik melakukan interpretasi dan analisa atas setiap peristiwa sejarah. Tugas guru sejarah pada proses pembelajaran adalah sebagai fasilitator dan evaluator. Namun pada akhir pembelajaran guru sejarah harus memandu peserta didik dalam melakukan konklusi.

\section{KESIMPULAN}

Dewasa ini pembelajaran sejarah mendapatkan tantangan yang kian berat. Salah satu tantangan pembelajaran sejarah ialah kemajuan teknologi. Kemajuan teknologi memberikan kemudahan bagi guru maupun peserta didik dalam mengakses berbagai sumber, informasi dan pengetahuan kesejarahan. Maka, kemajuan teknologi secara tidak langsung memberikan dampak pada pembelajaran sejarah. Namun, sayangnya pembelajaran sejarah sebagai sebuah proses terkadang masih didominasi oleh guru sejarah atau hanya berpusat pada guru.

Pembelajaran sejarah yang lebih didominasi oleh guru sejarah seringkali tidak diminati oleh peserta didik. Peserta didik merasa bosan dan mengalami kejenuhan, belum lagi jika guru menjadikan buku cetak sebagai satu-satunya sumber belajar. Peserta didik merasa tidak diberikan cukup kesempatan dalam pembelajaran sejarah. Selain itu pembelajaran sejarah seringkali masih didominasi pada kegiatan menghafal fakta dan data sejarah. Jika ada proses pengolahan fakta dan data sejarah, seringkali peserta didik hanya dilibatkan secara normatif. Guru sejarah lebih sering mendominasi pengetahuan sejarah, dan lupa jika peserta didik juga memiliki hak untuk berpikir dan mempertanyakan hasil interpretasi tersebut.

Pembelajaran sejarah yang ideal seharusnya memberikan kesempatan yang cukup bagi peserta didik untuk mengambangkan kemampuan berpikir kritis dan analitis. Salah satu cara agar kemampuan tersebut dapat berkembang ialah dengan memberikan kebebasan berpikir bagi peserta didik. Peserta didik harus dilibatkan dalam proses pengolahan fakta dan data sejarah. Hal ini dikarenakan salah satu tujuan pembelajaran sejarah ialah mengembangkan perilaku yang didasarkan pada nilai dan moral dalam setiap peristiwa sejarah. Keduanya didapatkan melalui proses berpikir atau penalaran oleh peserta didik. Pada proses penalaran atau berpikir peserta didik diharuskan berpikir secara logis dan sistematis. Jika proses pembelajaran masih didominasi oleh 
guru dan terbatas pada satu sumber, maka pemahaman akan nilai dan moral tentu tidak akan didapatkan.

Kebebasan berpikir berpengaruh pada proses pembelajaran dan peserta didik. Proses pembelajaran tidak hanya akan menjadi hidup, dalam artian menyenangkan dan komunikatif, melainkan juga peserta didik akan memahami, bahwa pembelajaran sejarah sebagai sebuah proses harus dianggap serius. Pembelajaran sejarah tidak akan berguna bagi peserta didik jika hanya diisi dengan menghafal fakta dan data. Melalui pembelajaran sejarah, peserta didik akan belajar proses berpikir secara nalar, yang kemudian mengembangkan kemampuan berpikir kritis dan analitis mereka. Selain itu, kebebasan berpikir di dalam pembelajaran sejarah akan mewujudkan pembelajaran sejarah yang sesuai dengan pandangan perenialisme, esensialisme dan kontekstual.

\section{DAFTAR PUSTAKA}

Absor, N. F. (2020). Pembelajaran Sejarah Abad 21: Tantangan dan Peluang dalam Menghadapi Pandemi Covid-19. CHRONOLOGIA, 2(1), 30-35.

Asep, J., \& Abdul, H. (2008). Evaluasi Pembelajaran. Yogyakarta: Multi Press.

Bochenski, J. M. (2001). Apakah Sebenarnya Berpikir. Jakarta: Yayasan Obor Indonesia.

Faisal, S. (2005). Format-format Penelitian. Jakarta: Raja Grafindo Persada.

Fakta, T. C. (2020). [KLARIFIKASI] Mata Pelajaran Sejarah Tidak Dihapus dari Kurikulum. Retrieved from kompas.com website:

https://www.kompas.com/tren/read/2020/09 /21/104053465/klarifikasi-mata-pelajaransejarah-tidak-dihapus-dari-kurikulum

Hasan, H. S. (2007). Kurikulum Pendidikan Sejarah Berbasis Kompetensi. In Disampaikan dalam Seminar Nasional
Ikatan Himpunan Mahasiswa Sejarah SeIndonesia (IKAHIMSI). Semarang: Universitas Negeri Semarang.

Kochhar, S. K. (2008). Pembelajaran Sejarah. Jakarta: Grasindo.

Matanasi, P. (2016). Mengapa Pelajaran Sejarah Tak Disukai. Retrieved from tirto.id website: https://tirto.id/mengapa-pelajaransejarah-tak-disukai-bUc2

Penguatan Pendidikan Karakter Jadi Pintu Masuk Pembenahan Pendidikan Nasional. (2017). Retrieved from kemdikbud.go.id website:

https://www.kemdikbud.go.id/main/blog/201

7/07/penguatan-pendidikan-karakter-jadi-

pintu-masuk-pembenahan-pendidikannasional

Peraturan Menteri Pendidikan Nasional Nomor 22 Tahun 2006 Tentang Standar Isi.

Santosa, Y. B. P. (2017). Problematika Dalam Pelaksanaan Pendidikan Sejarah Di Sekolah Menegah Atas Kota Depok. Jurnal Candrasangkala Pendidikan Sejarah, 3(1), 30.

https://doi.org/10.30870/candrasangkala.v3 i1.2885

Sjamsuddin, H. (2016). Metodologi Sejarah. Yogyakarta: Ombak.

Strauss, A., \& Corbin, J. (2009). Dasar-dasar Penelitian Kualitatif. Yogyakarta: Pustaka Pelajar.

Sugihartono, K. N. F., Harahap, F., Setiawati, F. A., \& Nurhayati, S. R. (2007). Psikologi Pendidikan. Yogyakarta: UNY Pers.

Sumantri, J. S. (2003). Filsafat IImu: Sebuah Pengantar Populer. Jakarta: Pustaka Sinar Harapan.

Suswandari, S., Lukman, L., \& Absor, N. F. (2020). Problems on History Teaching With Curriculum 2013 in Vocational High Schools in East Jakarta. International Proceedings Conferences Series, 233-237. 